\title{
オン・ザ・スポット
}

\section{Impact factor 亡「日本御危篤」}

中 村昌弘

日本医学図書館協会名誉顧問

昨年，久世光彦著「ニホンゴキトク」が出た。 勿論,「ニホンゴキトク」とは「日本語危篤」の ことである。例えば，辛抱が我慢になり，一丁前 は一人前になり, 半ちくは中途半端に, きまりが 悪いは䎵ずかしいになったりして，意味は同じで あ, 日本の伝統的雾囲気はなんとなく変化してい る。そして, 按配, 強情, 剣吞, 息災, 時分よ゙き, じれったい, 冥利に尽きるなどの美しい, 意味深 長な日本語が次々に死語となって, 安易な日本語 やカタカナに置き換えられるのを憂いたエッセイ 集である。久世氏の最も言いたかったのは「ニホ ンゴキトクスグカエレ」であったらしい。

同氏は「本」（読書人の雑誌・講談社）に「日 本御危篤」というエッセイを別に書いていて，句 読点の大切さと日本語の美しさを再強調している。 句読点については近松門左衛門の「ふたへにして くびにかけるじゅず」の例が出してあって, “し て，首にかける”と読むか，“し，手首”之読む かでまるで異なった数珠になる話。リズミカルな 日本語の例には太宰治の「晩年」の書き出しが引 用されている。「死のうと思っていた。今年の正 月，よそから着物を一反もらった。㧍年玉として である。着物の布地は麻であった。鼠色のこまか い縞目が織り込まれていた。これは夏に着る着物 であろう。夏まで生きょうと思った。」この文章 は弘前市の郷土文学記念館の太宰治のコーナーに あ掲げてある。日本人にとって，日本語の美しさ
というあのはこういうあのであろう。尤む，外国 語にあ美しい文章，上品な文章があって，それぞ れの国の人には捨てがたいあのがあろうが，それ あその国で生まれて育たないとなかなか理解でき ないあのであろう。

昨年 8 月, 産業医科大学で第 49 回九州地区医 学図書館協議会総会があった。その折，パネルディ スカッションのテーマとして「ネットワーク社会 における医学図書館の役割」があげられた。内容 はパソコンを用いた情報の検索，更にインターネッ 卜を利用したものまで最新の技術の紹介が三名の パネラーによってなされた。文献の検索がすべて 英文によるものであったので，既に大学を退いて 十数年を閲した身に甘んじて今更恥じでもなかろ うと思い，日本語で書かれた論文の評価はどうなっ ているのかと質問した。日本にはたくさんの学会 があり，それぞれ日本語でたくさんの学会機関誌 が出版されている。それらが Impact factor がゼ ロでは日本の医学は何と無駄なことをしているの かと思ったからである。最近，大学教員の任期制 あ検討中やに聞くし，教授選考のデータにはこの Impact factor で業績に点数が付けられ，教授が 選ばれるのである。基礎医学教授の場合は一応そ れでいいとしても，臨床教授の選考に Impact factorのみを資料とされたら，臨床ばかりに携 わっている人には教授に選ばれる可能性は極めて 少ないことになる。ほとんどが日本語で書かれた 
一例報告であったり, 治験であったり, 統計であっ たりするからである。臨床医で Impact factor を 高めるにはどうしてあ基礎医学で研究する以外に 方法はないように思われる。Nature とか Science とかに載せる論文は臨床のみをやっている人には 到底，書くような機会はないと思う。

従って，日本語の論文にも，少なくとも国内だ けに通用するすのであいいから和式 Impact factor を作れないあのかと質問と私見を述べる つありでいた。そこまで私の発言が進まないうち に, ある大学の図書館長から，君は日本語無用論 を言っているのかと強い語調で中断させられた。 同館長の説明では, 日本語の論文は出版後, 一力 月以内に英語に訳されているとの指摘であった。 私は前にあ述べたように退職後十数年たっていて, そういうことは昔はなかったが, 最近, 和文論文 が直ちに翻訳されるようになったとは全く知らな かったので，勿論，反論できなくて，発言は途中 で止した。

しかし，あし，そういうことがなされているな ら日本語の論文にも当然, 何がしかの Impact factor は点数として付けられているはずである。 雑誌「医学図書館」1996；43(1)：87-93，に深川 光郎・吉田幸子著「MEDLINE 収録誌を対象と したインパクト・ファクターの分析」という論文 がある。この論文の目的は国内誌がインパクト・ ファクターの対象誌として 1 誌でも多く収録され, 国際的な評価が上がることを切望することにある という。中身を読むと, 日本語のみで書かれて MEDLINE と SCI/JCR に収録されているのは Yakugaku Zasshi のみである。他はすべて英語
で書かれたあのである。そうであるならば，学会 がそれぞれ出版している日本語の学会誌に, いっ たいどんな意味があるのであろうか。日本の医学 は世界のトップレベルにあると言うが，せっかく 出版された和文の論文がただ日本人だけのあので あるのは何としてあ勿体ない。

「医学図書館」 1997 ; 44(1)の Book Review に 青木仕氏による「科学を計る」という本の紹介が ある。その中に「日本語で書かれ，日本の雑誌に 載った論文がすべて二流だとは言い切れないが...」 と述べてある。これを逆説的にとれば, 日本語で 書かれた論文は，はじめから一流ではないと言う ことを意味していることにもなる。アメリカや英 国の研究者は英語でしか論文を書くことができな い，そして書いた論文はすべて Impact factor の 何点かになる。全く, 結構な話である。従って, 国そのものがはじめから一流であることを意味し ている。それでは, 日本, 韓国, 中国, ロシアな どは何時までたってあ科学の分野では一流になる ことは不可能と言い得る。では, たくさんの紙を 消費する国内学会誌に一体何の価值があろう, 浪 費ではなかろうか。更に，毎年開催され，たくさ んのお金を使う学会そのものさえ果たしてどんな 意味があるのであろうか, 何とかしてこれらに国 際的意味づけができないものかと最近つくづく考 える次第である。

このままであるならば，それこそ「日本御危篤」 である。

ただ, 少し疑問なのは川端康成, 大江健三郎の ノーベル文学賞決定のための Impact factor はど うして計算するのであろうか。 